\title{
NOVEL OXYGEN-STEAM GASIFICATION PROCESS FOR HIGH QUALITY GAS FROM BIOMASS
}

\author{
Marek Dudyński * \\ Modern Technologies and Filtration Sp. z o.o., ul. Przybyszewskiego 73/77 lok. 8, 01-824 Warszawa, Poland
}

Article Info:
Received:
13 November 2018
Revised:
3 April 2019
Accepted:
8 April 2019
Available online:
19 May 2019
Keywords:
Biomass gasification
Oxygen reforming
Gas engine

Article Info:

13 November 2018

Revised:

3 April 201

8 April 2019

Available online:

19 May 2019

Biomass gasification

Gas engine

\begin{abstract}
We present the design of a novel oxygen-steam-air updraft gasification plant and technological process capable of delivering high quality producer gas. Gas with calorific value of $8 \mathrm{MJ} / \mathrm{m}^{3}$ is cleaned with an absorption type gas purification unit and then coupled with a piston engine for electricity production with $31 \%$ efficiency. We present the results of test runs of the installation with various combinations of gasification agents and plasma torch influence on gas quality and tar removal. We have used a classical hot plasma torch for tar cracking, but it creates a problem with proper gas mixing with very high temperature flame requiring special design of the mixing chamber. In the future development we plan to install a cold plasma reactor for more selective heavy tar reforming prior to gas entering purification unit.
\end{abstract}

\section{INTRODUCTION}

Gasification systems can be used for effective energy production in a variety of ways (Arena et al. 2010, BangMøller et al. 2010, Dudyński 2018). The conventional solution of generating energy from locally produced biomass waste, wood pellets or chips utilizes steam generation process, which is then used for integrated heat and/or electricity production (Dudyński et al. 2012, Dudyński 2018). Analogous solution has found widespread use in cogeneration installations (Kirsanovs et al. 2017), but the electric energy effectiveness of simple turbines is usually far below $20 \%$ for small systems. Improvements are possible with the application of a gas engine, but such solutions are still under development. Systems now in operation mainly downdraft type or combining wood pyrolysis with gasification of chars - are quite complicated and costly in maintaining (Farzad et. al. 2016). All of those need special electric energy tariffs to operate profitably. More advanced systems, using micro turbines or fuel cells, while promising are currently in research stage, although the technology has been successfully demonstrated in several regions globally, including systems operating in Europe. (Santarelli M. et al. 2017), (Brunaccini G. et al. 2017), (Kupecki J. et al. 2017), (Kupecki J. et al. 2016). Fuel cells-based systems are therefore at the level of subsidized early market penetration and are still under development. Commercial small scale unsubsidized operating systems produce mainly heat or steam used in host production plants (Dudyński 2018) and the market breakthrough for electricity producing units is dependent on significant reduction of construction and operating costs.

The fixed bed, updraft gasification systems are more robust, reliable and easy to scale up to higher capacities when compared to other gasification systems but require effective gas cleaning units and improvements of syngas quality to achieve successful coupling with a piston engine. One of the most promising methods to achieve this objective is to replace the air as a gasification agent with oxygen enriched air mixed with steam to enhance the calorific value of the gas and limit the tar levels (Liu et al. 2018). We developed a gasification fixed bed $2 \mathrm{MW}$ unit which can operate with hot air, hot air - steam combination and $40 \%$ oxygen air - steam - hot air combination as gasification agents. We use heat from producer gas cooling to heat up the primary and secondary air to temperatures above $250^{\circ} \mathrm{C}$. The primary air can be mixed with $186^{\circ} \mathrm{C}$ steam to form controllable gasifying gases we inject into the chamber in the bottom of the installation. Combination of these two gasses allows us to operate in two distinct modes.

Low bed height - low steam content in primary air which can be applied for wet low calorific fuels. The producer gas has a temperature above $750^{\circ} \mathrm{C}$ at the outlet, LHV $3,5 \mathrm{MJ} / \mathrm{m}^{3}$ and less than $5 \mathrm{~g} / \mathrm{m}^{3}$ of tars.

High bed height - high steam air ratio in primary air, effective for dry, high calorific fuels. The gas temperatures in the gas chamber is below $500^{\circ} \mathrm{C}$, the LHV above $5 \mathrm{MJ} / \mathrm{m}^{3}$ and tar content above $10 \mathrm{~g} / \mathrm{m}^{3}$.

For dry wood, we can enhance the effect of mixed gasifying gases by adding air with $40 \%$ oxygen content to im- 
prove the producer gas quality. Details of the design and results of syngas generation for dry wood chips and different composition choices of the gasification agent are presented below.

\section{THE GASIFICATION UNIT}

We have developed a new, oxygen-steam-air driven biomass gasification system and process capable of producing syngas with calorific value up to $8 \mathrm{MJ} / \mathrm{m}^{3}$ on a tar free basis. This device is an improvement of the biomass gasification units successfully used in many industrial plants in Poland, intended for energy production using waste from technological processes as a fuel (Kwiatkowski et al. 2013, Dudyński 2018). The operating scheme of the system is presented on Figure 1.

The fuel is fed into the gasifying chamber at the upper part of the device through two separate dosing systems located symmetrically on both sides of the unit to secure more uniform level of bed formation. The chamber is 2.5 $\mathrm{m}$ in width a $4.5 \mathrm{~m}$ in height. The bed height is $3,5 \mathrm{~m}$ while operating in high bed mode in order to accommodate dry wood chips feed, separated graphically on Figure 1 into ash, gasifying, pyrolysis and drying zones.

At the bottom we placed a sophisticated ash removal system coupled with steam and air injection in the form of four rotating conical grates each equipped with two ploughshares moving ash to the receiving auger presented on Figure 2.

Conical grates operate in the ash and carbon layer at the bottom of the gasifier where the final carbon burn out takes place. A combination of hot air-steam-oxygen rich air is fed into the gasifier through each of the four rotating elements made of cast iron with very high chrome content in order to withstand the temperatures of the process. The

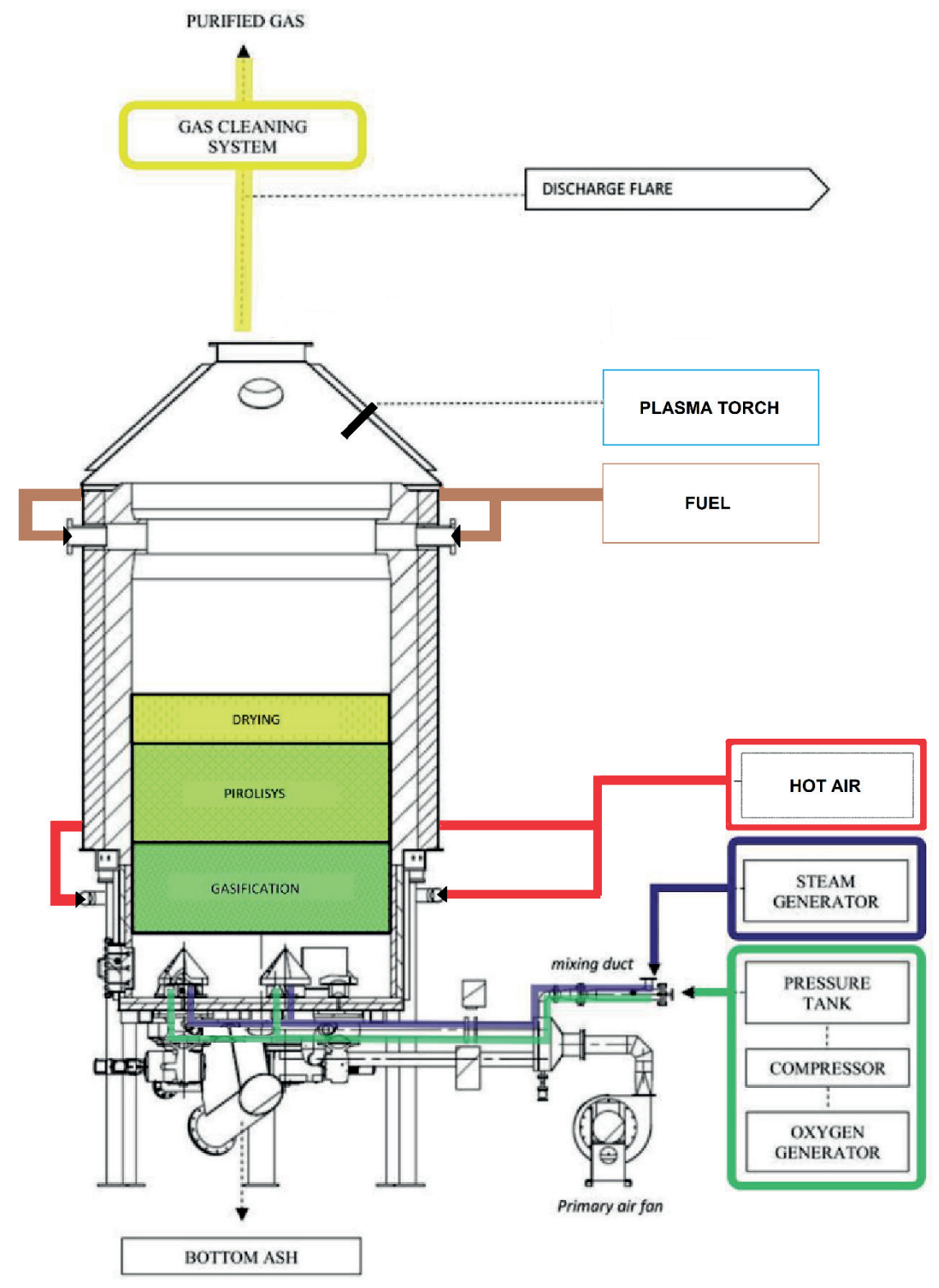

FIGURE 1: Operating scheme of the biomass gasifying unit. 


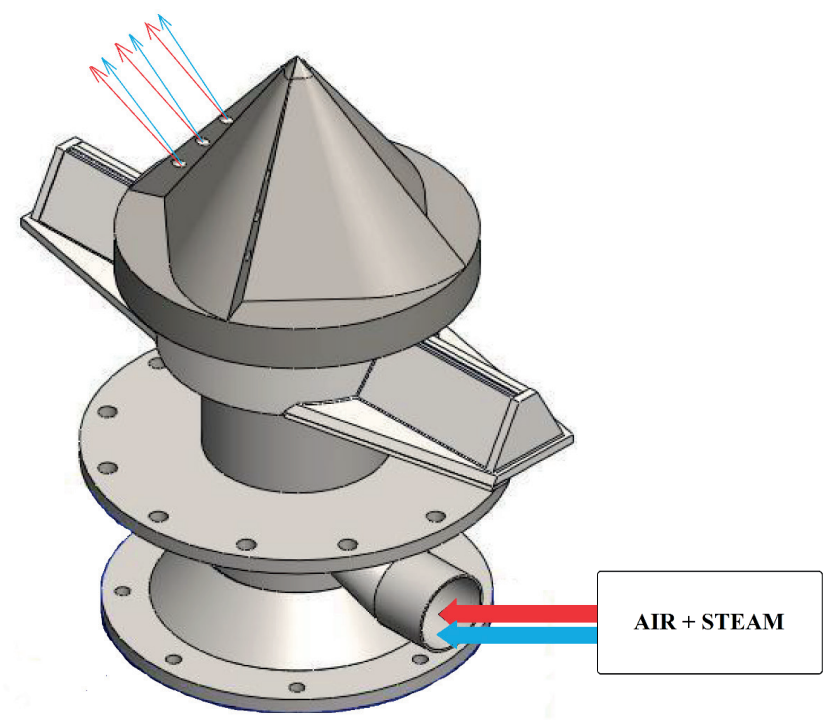

FIGURE 2: The conical moving element.

slow rotating movement of the grate mixes the materials and pushes the ash into the receiving augur.

The heat removed from the producer gas by the gas cleaning system is used to heat up the primary and secondary air to $250^{\circ} \mathrm{C}$. The $186^{\circ} \mathrm{C}$ overheated steam with 4 bar pressure is produced in electrically heated steam generator at a rate up to $100 \mathrm{~kg} / \mathrm{h}$.

The oxygen rich air, containing up to $40 \%$ of oxygen and flow speed standing at 100 is produced in a separate unit utilizing the molecular sieves method. These air streams are mixed with steam prior to being applied in gasification process. The role of steam is twofold. First it performs as an oxygen dispersive medium preventing occurrences of high temperature spots at the bottom of the gasifier, where the char and gas burning processes are the most intense. Application of $40 \%$ of oxygen air can cause temperatures to locally reach $1800^{\circ} \mathrm{C}$ causing serious damage to the structure and equipment, with steam and additional air lowering the oxygen content to a maximum of $25 \%$ of gas volume, the temperatures in the bottom part of the gasifying chamber are kept below $1200^{\circ} \mathrm{C}$ ensuring that the operation is smooth and safe. The hot gases move up in the chamber and in the upper part of the gasification unit the overheated steam and $\mathrm{CO}_{2}$ can react with fixed carbon and tars to produce $\mathrm{CO}$ and $\mathrm{H}_{2}$ in a water shift reaction, efficient in high temperatures:

$\mathrm{C}+\mathrm{H}_{2} \mathrm{O} \rightarrow \mathrm{CO}+\mathrm{H}_{2}+131.28 \mathrm{~kJ} / \mathrm{kmol}$ (endothermic)

$\mathrm{CO}+\mathrm{H}_{2} \mathrm{O} \rightarrow \mathrm{CO}_{2}+\mathrm{H}_{2}-41.15 \mathrm{~kJ} / \mathrm{kmol}$ (exothermic)

$\mathrm{C}+\mathrm{CO}_{2} \rightarrow 2 \mathrm{CO}+172 \mathrm{~kJ} / \mathrm{kmol}$ (endothermic)

improving significantly the producer gas quality and generally lowering temperatures in the carbon burning zone. We constructed a unit allowing for various combinations of gasification gases delivered via a multilayer and multipoint injection system. At the bottom of the gasifier four rotating cones equipped with multiple inlets serve as main injection ports. The oxygen rich air mixed with steam is delivered into the bottom part of the unit through these cones. Approximately $50 \%$ of the oxygen necessary for the gasification process is provided through these four injection ports and most of the necessary hot $\mathrm{CO}_{2}$ and $\mathrm{H}_{2} \mathrm{O}$, is produced in the bottom area of the reactor. The remaining air necessary for the process is injected by 32 nozzles located above the cones, close to the bottom of the pyrolysis zone. The delivered air reacts with the hot pyrolytic carbon producing $\mathrm{CO}$ - rich gases and extending the high temperature zone in the gasifier - intensifying the process of wood drying and carbonizing. Such construction guarantees a more uniform distribution of gases and wood chips in the chamber, and therefore improves the mixing of carbonized material with gasifying agents. This enhances the effectiveness of gas production and unification of the temperature's distribution in the gasification process. The control unit allows us to continuously change the parameters and the composition of gasifying gases leading to better control of the producer gas parameters.

Gas leaving the gasification unit still contains high amounts of carbon dust and heavy hydrocarbons as shown in Table 1, which must be removed before gas is fed into the engine.

With such high levels of tars and carbon dust the produced gas requires a very efficient purification system. There are various methods of gas cleaning and virtually every wood gasification unit developed their own unique technology (Boerrgter et al. 2004), (Bocci et al. 2010). In our case we designed an absorptive system presented on Figure 3 coupled with a $20 \mathrm{~kW}$ plasma torch located at the exit of hot gases from the gasification chamber where an upper part of the chamber was used for syngas mixing with very hot plasma flame. This allows for an analysis of the influence of plasma on the composition of producer gas and heavy tars content.

The gas cleaning system consists of a cyclone integrated with the gasifier outlet (not shown on the drawings), with ceramic lining capable of withstanding temperatures of up to $1200^{\circ} \mathrm{C}$, which removes part of carbon dust and as we see on Figure 3 an absorptive unit composed of an airgas exchanger (cooler 1), water scrubber (3) for dust and impurities removal, two water operated coolers (2) able to lower the syngas temperature to $60^{\circ} \mathrm{C}$, an oil scrubber (4) and an active carbon filter (5). On the Figure 4 . we present the operating scheme of the absorptive gas cleaning unit where the technology of the process and the mass flow can be seen.

The syngas cleaning takes place by precipitation and removal of tars and heavy hydrocarbons contained therein by adequate cooling of the gas in several stages and absorption of light impurities in the syngas by directing the gas flow through two absorption devices (scrubbers). The first scrubber uses water and the other fuel oil as absorbent. Both scrubbers are equipped with demisters placed immediately before the outlet, which keeps the scrubbing liquids inside the apparatus. Up to $800 \mathrm{~m}^{3} / \mathrm{h}$ of gas, at temperatures up to $750^{\circ} \mathrm{C}$, resulting from the gasification of wood is transported to the first exchanger (cooler 1 ) in a counter-current system, where the gas will be cooled to temperatures in the range of $105-110^{\circ} \mathrm{C}$ and the concurrent air heated up to $250^{\circ} \mathrm{C}$. 
TABLE 1: Properties of the producer gas.

\begin{tabular}{|c|c|c|c|}
\hline Substance & $\begin{array}{c}\text { Run 1 } \\
{\left[\mathrm{mg} / \mathrm{Nm}^{3}\right]}\end{array}$ & $\begin{array}{c}\text { Run 2 } \\
{\left[\mathrm{mg} / \mathrm{Nm}^{3}\right]}\end{array}$ & $\begin{array}{c}\text { Run 3 } \\
{\left[\mathrm{mg} / \mathrm{Nm}^{3}\right]}\end{array}$ \\
\hline Dust & 1700 & 2120 & 1860 \\
\hline Benzene & 73.6 & 147.3 & 117.3 \\
\hline Toluene & 6050 & 12700 & 12810 \\
\hline Xylene & 210 & 450 & 440 \\
\hline Sum of BTX * & 8380 & 18040 & 16230 \\
\hline Naphtalene & 1.83 & 0.20 & 0.21 \\
\hline Acenaphthylene & 0.20 & 0.86 & 0.77 \\
\hline Acenaphthene & 0.05 & 0.18 & 0.17 \\
\hline Flurene & 0.42 & 1.26 & 1.15 \\
\hline Phenanthrene & 2.63 & 7.24 & 6.43 \\
\hline Anthracene & 0.69 & 1.93 & 1.76 \\
\hline Fluoranthene & 1.22 & 4.09 & 4.86 \\
\hline Pyrene & 1.19 & 4.27 & 5.35 \\
\hline Benzo [a] anthracene & 0.33 & 0.92 & 1.24 \\
\hline Chrysene & 0.28 & 0.83 & 1.10 \\
\hline Benzo[b]fluoranthene & $<0.01$ & 0.80 & 1.66 \\
\hline Benzo(j)fluoranten & 0.31 & 0.80 & 1.61 \\
\hline Benzo(k)fluoranten & 0.11 & 0.31 & 0.48 \\
\hline Benzo[a]pyrene & 0.26 & 0.75 & 1.21 \\
\hline Indeno[1,2,3-cd]pyrene & 0.13 & 0.32 & 0.51 \\
\hline Benzo[ghi]perylene & 0.18 & 0.50 & 0.77 \\
\hline Sum of polycyclic aromatic hydrocarbon compounds & 9.82 & 25.25 & 29.27 \\
\hline
\end{tabular}

In the first stage of cooling, heavy tar fractions precipitate and flow down the device from where they can be collected.

Then the gas flows to the water scrubber, where it is cleaned of larger impurities, dust and water-soluble elements. After passing through the water scrubber, the gas moves to the fan and then is pressed to a two-stage heat exchanger system where in the second and third levels of cooling, the temperature of the gas drops below the precipitation point of tar and light hydrocarbons which flow with water down the walls of the exchangers into the lower parts, where a discharge spigot enables the liquefied contaminants to be collected. An important factor determining the possibility of precipitation of tars, preventing the formation of carbon deposits and clogging of exchangers is to maintain appropriate temperatures at the inlet and outlet of each cooler. The gas will then be fed to the absorption column (oil scrubber), where the residual tars will be washed away by the oil. After final cleaning in the active carbon candle filter the gas can be transported to the engine or directed to the combustion chamber.

The oil flowing through the scrubber is pumped to the clarifier and then to a candle filter unit. The purified and cooled oil is then returned to the absorption column (oil scrubber).

The water flowing through the scrubber is pumped to a clarifier and then recycled to the installation.

\section{THE RESULTS}

The final plant integrates the gasification, purification, oxygen and steam generation units with piston engine, can generate $500 \mathrm{~kW}$ of electricity and use the excess heat for wood chips drying.

The system can operate on wood chips or pellets, with both air-steam mixtures and oxygen enriched gasification gases. We tested the process with dry wood chips with $20-25 \%$ humidity and average diameter of $10-30$. We have compared the producer gas quality during simple air gasification (Run 1) with mixture of air and steam (Run 2) and finally with steam-oxygen-air composition (Run 3). The results are summarized in Table 2.

The amount of wood used in each test was dependent on the effectiveness of the gasification process as the level of material in the gasifying chamber was kept constant. In all tests the amount of oxygen in gasification gases was also kept constant and equal to $120 \mathrm{~kg} / \mathrm{h}$ with different combination of air, steam and oxygen enriched air making the results directly comparable. We observe the differences in thermal output of each run showing the dynamics of the process measured in effective amount of wood gasified during each test.

We have introduced changes of gasification gases during consecutively executed runs as presented on Figure 4. This allows for a direct comparison of the effects of dif- 


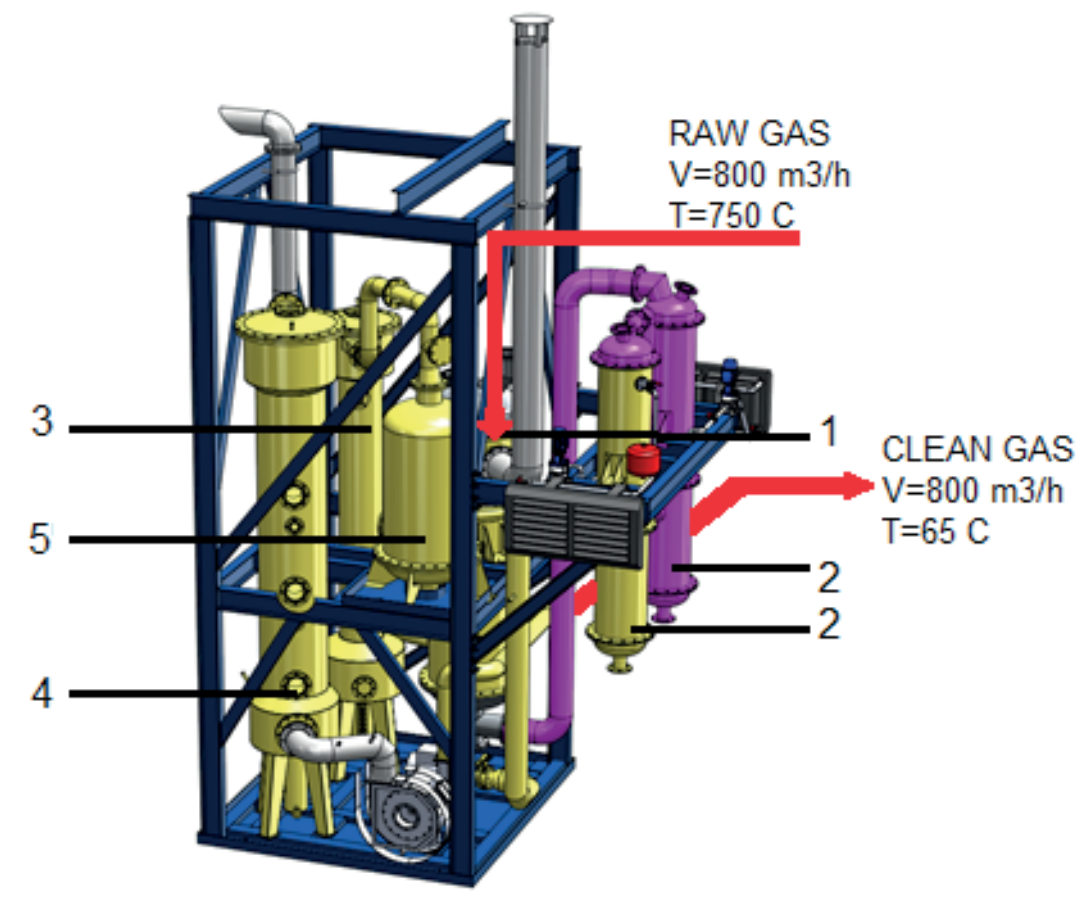

FIGURE 3: 3D scheme of gas purification unit. 1. First cooler, 2. Water coolers, 3. Water scrubber, 4. Oil scrubber, 5. Carbon filter.

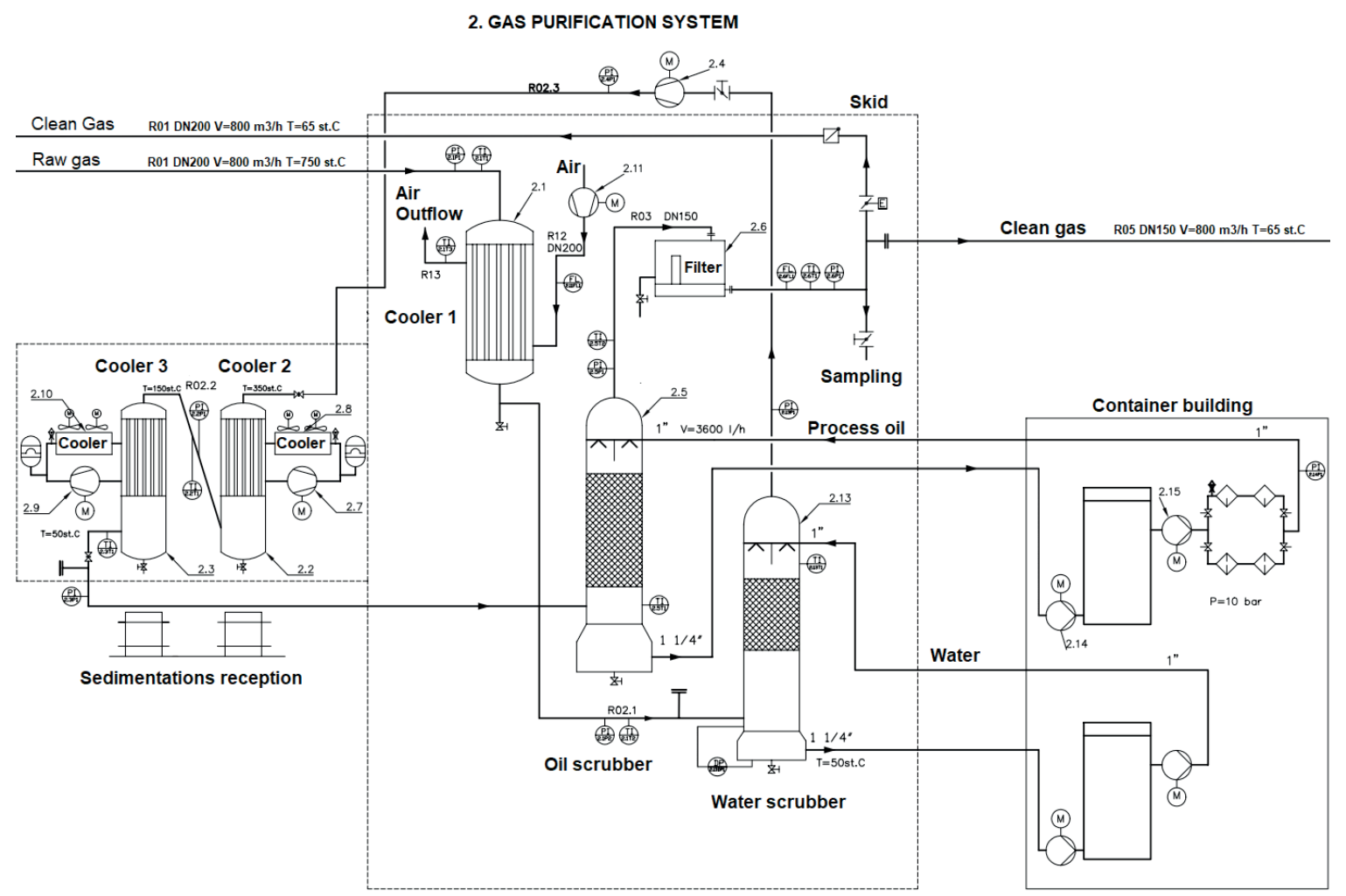

FIGURE 4: Operating scheme of a gas purification unit.

ferent factors on the quality of obtained producer gas and the stability of the process. We have measured the tar contents of the gas leaving the gasifier and the composition of tars collected in various stages of the purification process during each run. On Figure 5 we present the gas composition and LHV of the gas leaving the purification unit.
The results clearly indicate that the application of various combination of oxygen, steam and air composition significantly influences the properties of the producer gas leading to significant grow of calorific value but not necessary lowering the amount of tar and light hydrocarbons in the raw gases as is clearly seen in the Table 1 . The compo- 
TABLE 2: Parameters of the process and properties of the producer gas after purification.

\begin{tabular}{|c|c|c|c|}
\hline & Run 1 & Run 2 & Run 3 \\
\hline \multicolumn{4}{|l|}{ Parameter } \\
\hline Thermal output [MW] & 1.35 & 1 & 1.8 \\
\hline Fuel [kgh-1] & 300 & 225 & 380 \\
\hline Air flow $\left[\mathrm{m}^{3} \mathrm{~h}^{-1}\right]$ & 600 & 500 & 400 \\
\hline Oxygen content [\%] & 21 & 21 & 25.75 \\
\hline Steam flow $\left[\mathrm{kgh}^{-1}\right]$ & 0 & 20 & 20 \\
\hline \multicolumn{4}{|c|}{ Syngas Parameters After Purification } \\
\hline $\mathrm{CO}[\%]$ & 29.30 & 26.47 & 34.05 \\
\hline $\mathrm{H}_{2}[\%]$ & 10.75 & 8.35 & 22.30 \\
\hline $\mathrm{CH}_{4}[\%]$ & 2.57 & 1.80 & 4.04 \\
\hline $\mathrm{CO}_{2}[\%]$ & 8.42 & 7.56 & 16.39 \\
\hline Syngas LHV [MJm-3] & 5.45062 & 4.58903 & 7.76995 \\
\hline
\end{tabular}

sition of tar in water collected at the third cooler is presented in Table 3.

These results are representative for all the condensates collected in all three coolers where we find mainly water and the hydrocarbons content does not exceed $0.5 \%$ of the collected water.

Finally, we chose the oxygen, air and steam composition for the long - term tests including integration of the gasification unit with a piston engine for electricity generation. The time stability of the clean gas composition generated during a test is presented on Figure 6.

The gas leaving the purification system is relatively almost tar free as shown on Table 4, with both heavy and lights hydrocarbons components virtually absent.
This shows that the absorptive systems are too reactive - removing not only heavy but also light hydrocarbons as well and unnecessarily lowering the calorific value of the gas, while generating more waste water and oil, then necessary for the process of production of fuel-grade syngas. More selective systems, eliminating heavy hydrocarbons only, can be less cumbersome and more effective for this purpose and shall be looked for.

We observe that the plasma torch seems to lower the amount of heavy tars transforming them into light hydrocarbons, which is promising, but a $20 \mathrm{KW}$ torch is not enough to replace the purification unit for $800 \mathrm{~m}^{3} / \mathrm{h}$ volume of producer gas and a much powerful unit will be tested but it shall require a significant amount of produced power to

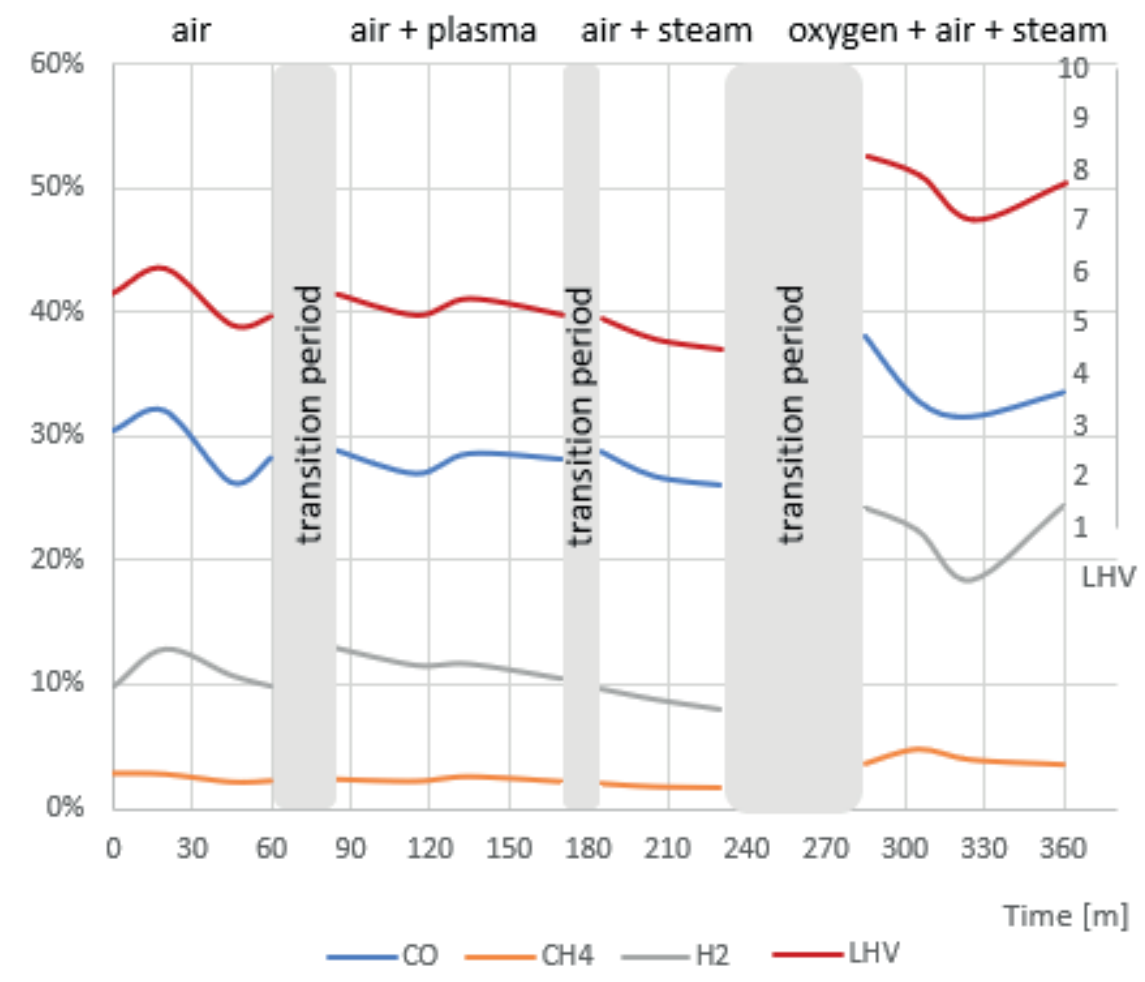

FIGURE 5: The composition and LHV of producer gas. 
TABLE 3: Hydrocarbon concentration in condensed water from cooler III.

\begin{tabular}{|c|c|c|c|}
\hline Compound & Retention time & Concentration [\%] & Crystalization temperature $\left[{ }^{\circ} \mathrm{C}\right]$ \\
\hline Acetaldehyde & 5.255 & 0.022 & -123 \\
\hline Butanal & 9.227 & 0.002 & -97 \\
\hline Toluene & 14.501 & 0.006 & -95 \\
\hline Acentone & 6.68 & 0.026 & -94 \\
\hline 2-Butanone,3-methyl- & 11.323 & 0.001 & -92 \\
\hline 2-Propenal & 6.575 & 0.001 & -88 \\
\hline 2-Butanone & 9.353 & 0.009 & -86 \\
\hline 2-Pentanone & 12.134 & 0.002 & -86 \\
\hline Methacrolein & 8.603 & 0.003 & -81 \\
\hline Cyclopentanone,2-methyl- & 16.141 & 0.002 & -75 \\
\hline Cyclopentanone & 14.972 & 0.002 & -58 \\
\hline 3-Buten-2-one,3-methyl & 11.747 & 0.005 & -54 \\
\hline 2,3-Pentanedione & 12.312 & 0.002 & -52 \\
\hline Indene & 19.98 & 0.004 & -25 \\
\hline 1,3,5,7-Cyclooctatetraene & 17.262 & 0.002 & -4 \\
\hline 2,3-Butanedione & 9.084 & 0.015 & -3 \\
\hline 2-Cyclopentene-1-one, 2-methyl- & 17.466 & 0.002 & 2 \\
\hline Benzene & 11.519 & 0.034 & 5.5 \\
\hline Creosol & 21.776 & 0.005 & 5.5 \\
\hline Phenol, 2-methoxy- & 20.445 & 0.003 & 28 \\
\hline Phenol, 2-methyl- & 19.799 & 0.004 & 34 \\
\hline Phenol, 2-methyl- & 20.083 & 0.002 & 34 \\
\hline Phenol & 18.643 & 0.002 & 40.5 \\
\hline Phenol, 2,6-dimethyl- & 20.691 & 0.001 & 47 \\
\hline Phenol, 2,6-dimethyl- & 21.125 & 0.003 & 47 \\
\hline 4-Methylphthalic anhydride & 19.175 & 0.001 & 91 \\
\hline Azulene & 22.028 & 0.006 & 99 \\
\hline
\end{tabular}

TABLE 4: Hydrocarbon concentration in clean producer gas.

\begin{tabular}{|c|c|c|c|c|c|c|}
\hline Name & $\begin{array}{l}\text { Retention } \\
\text { time }\end{array}$ & $\begin{array}{c}\text { Concentration } \\
{[\%]}\end{array}$ & $\begin{array}{c}\text { Concentration } \\
{\left[\mathrm{mg} / \mathrm{Nm}^{3}\right]}\end{array}$ & $\begin{array}{c}\text { Temperature of } \\
\text { crystallization }\left[{ }^{\circ} \mathrm{C}\right]\end{array}$ & $\begin{array}{c}\text { Boiling } \\
\text { temperature }\left[{ }^{\circ} \mathrm{C}\right]\end{array}$ & $\begin{array}{c}\text { Molar mass } \\
{[\mathrm{g} / \mathrm{mol}]}\end{array}$ \\
\hline $\begin{array}{l}\text { 2-Propanol, 1-Me- } \\
\text { thoxy }\end{array}$ & 9.709 & 0.001 & 11 & -96.00 & 120.00 & 90.12 \\
\hline Toluene & 12.283 & 0.010 & 110 & -95.00 & 110.6 & 92.14 \\
\hline $\begin{array}{l}\text { Formic acid, } \\
\text { 10methylethyl } \\
\text { ester }\end{array}$ & 7.290 & 0.003 & 33 & -93.00 & 68.00 & 88.11 \\
\hline 2-Butanone & 7.712 & 0.002 & 22 & 86.00 & 79.6 & 72.11 \\
\hline Isopropyl acetate & 9.240 & 0.010 & 110 & -73.00 & 89.00 & 102.13 \\
\hline Nonane & 15.580 & 0.001 & 11 & -53.00 & 150.4 & 128.26 \\
\hline Benzene & 9.268 & 0.035 & 385 & 5.5 & 80.1 & 78.11 \\
\hline $\begin{array}{l}\text { Propanoic acid, } \\
\text { 1-methylethyl ester }\end{array}$ & 11.692 & 0.001 & 11 & -88.00 & 108.00 & 116.16 \\
\hline $\begin{array}{l}\text { 5-Norbornane- } \\
\text { 2-carboxaldehyde }\end{array}$ & 18.484 & 0.005 & 55 & - & $67(12 \mathrm{~mm} \mathrm{Hg})$ & 122.16 \\
\hline $\begin{array}{l}\text { Bicyclo[3.2.0]hept- } \\
\text { 2-ene, 2-methyl }\end{array}$ & 18.885 & 0.001 & 11 & & 158.00 & 108.10 \\
\hline $\begin{array}{l}\text { 2-Acetyl-5-norbor- } \\
\text { nene }\end{array}$ & 20.125 & 0.003 & 33 & & 191.00 & 136.19 \\
\hline SUM & - & 0.074 & 803 & - & - & - \\
\hline
\end{tabular}




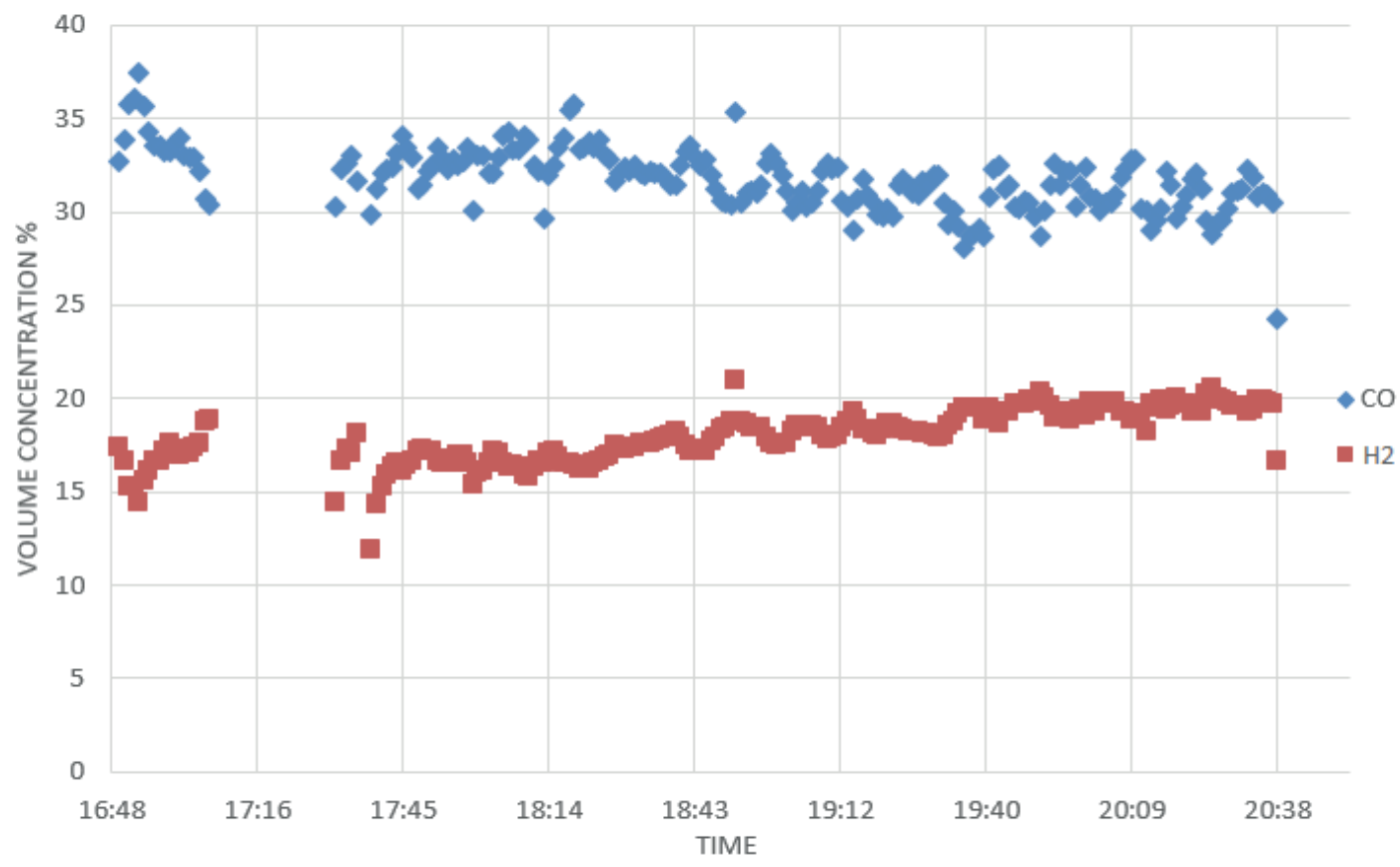

FIGURE 6: Composition of gas leaving the purification unit.

be spent on gas purification lowering the effective efficiency of the system.

The gas leaving the unit is wet, thus it is necessary to heat it up to $70^{\circ} \mathrm{C}$ with heat exchanger in order to successfully feed it to the engine. The whole unit with necessary adjustments in the engine control system, introduced to account for the fluctuations of the gas quality, worked satisfactory and achieved $31 \%$ of overall electric efficiency. We are currently working to reuse the spent water from the scrubber for steam generation and utilize the tars separated in coolers or used scrubber oil as a source of heat in the steam production unit.

\section{CONCLUSIONS}

There are many steam-oxygen gasification schemes recently tested (Kurkela et al. 2016, Broer et al. 2015) on laboratory or small-scale units indicating the potential of this method to improve the technology of biomass gasification (Baláš et al. 2016). We used the robust fixed bed, updraft gasifier for conducting such tests on the moderate $1.5 \mathrm{MW}$ scale. Application of the oxygen-steam-air combination improve significantly the LHV of the producer gas to the levels comparable with downdraft gasifiers (Wei et al. 2009) cited the gas calorific value of gas for downdraft system as $6.7 \mathrm{MJ} / \mathrm{m}^{3}$ and $14 \mathrm{mg} / \mathrm{m}^{3}$ of tar while (Omar at al.2018) with application of the hot air and steam gasification were able to reach $8 \mathrm{MJ} / \mathrm{m}^{3}$ and $1.8 \mathrm{~g} /$ $\mathrm{m}^{3}$ of tar for small scale $24 \mathrm{~kW}$ apparatus. We were able to achieve stable production of equally high quality, tar-free, $8 \mathrm{MJ} / \mathrm{m}^{3}$ producer gas which was used in an engine for uninterrupted electric energy generation with overall $31 \%$ efficiency. These results prove that such technology can be commercially applied for effective heat and electricity generation. Excess of heat is used for drying wood chips while waste oil, water and tars are to be used internally in the process.

\section{ACKNOWLEDGEMENTS}

This research was partially supported with ERA Bioenergy Advanced Biomass CCHP on gasification, SOFC and cooling machines ERA grant.

\section{REFERENCES}

Arena, U., Di Gregorio, F., \& Santonastasi, M. (2010). A techno-economic comparison between two design configurations for a small scale, biomass-to-energy gasification-based system. Chemical Engineering Journal, 162(2), 580-590.

Baláš, M., Lisý, M., Moskalǐk, J., \& Skála, Z. (2016). Steam influence on biomass gasification process. The holistic approach to environment, 6(3), 127-132.

Bang-Møller, C., \& Rokni, M. (2010). Thermodynamic performance study of biomass gasification, solid oxide fuel cell and micro gas turbine hybrid systems. Energy Conversion and Management, 51(11), 2330-2339.

Bocci E.,Sisinni M., Moneti M., Vecchione L.,DiCarlo A., Villarini M. (2014).State of the art of small scale biomass gasification power systems: a review of the different typologies. Energy Procedia 45,247-256.

Broer, K. M., Woolcock, P. J., Johnston, P. A., \& Brown, R. C. (2015). Steam/oxygen gasification system for the production of clean syngas from switchgrass. Fuel, 140, 282-292.

Boerrigter,H., Calis H.P., D.J. Slort D.J., Bodenstaff H., Kaandorp A.J., den Uil H., Rab L.M. (2004) Gas Cleaning for Integrated Biomass Gasification (BG) and Fischer-Tropsch (FT) Systems. ECNC--04-056.

Brunaccini G., Sergi F., Aloisio D., Ferraro M., Blesznowski M., Kupecki J., Motylinski K., Antonucci V., Modeling of a SOFC-HT Battery hybrid system for optimal design of off-grid base transceiver station, International Journal of Hydrogen Energy 2017;42(46):2796227978.

Dudyński, M., Kwiatkowski, K., \& Bajer, K. (2012). From feathers to syngas-technologies and devices. Waste Management, 32(4), 685-691.

Dudyński, M. (2018). Gasification of Selected Biomass Waste for Energy Production and Chemical Recovery. Chemical Engineering Transactions 65,386-391. 
Fabry F., Rehme C., Rohan V., Fulcheri L. (2013) Waste Gasification by Thermal Plasma: A Review. w. Waste and Biomass Valorization, Springer, VAN GODEWIJCKSTRAAT 30, 3311 GZ DORDRECHT, NETHERLANDS, 2013, 4 (3), pp.421-439.

Farzad S., Mandegari M.A., Görgens J.F. (2016) A critical review on biomass gasification, co-gasification, and their environmental assessments. Biofuel Research Journal 12, 483-495.

Kirsanovs, V., Blumberga, D., Karklina, K., Veidenbergs, I., Rochas, C. Vigants, E., \& Vigants, G. (2017). Biomass gasification for district heating. Energy Procedia, 113, 217-223.

Kurkela, E., Kurkela, M., \& Hiltunen, I. (2016). Steam-oxygen gasification of forest residues and bark followed by hot gas filtration and catalytic reforming of tars: Results of an extended time test. Fuel Processing Technology, 141, 148-158.

Kupecki J., Skrzypkiewicz M., Wierzbicki M., Stepien M., Experimental and numerical analysis of a serial connection of two SOFC stacks in a micro-CHP system fed by biogas, International Journal of Hydrogen Energy 2017:42(5):3487-3497.

Kupecki J., Skrzypkiewicz M., Stefanski M., Stepien M., Wierzbicki M., Golec T., Selected aspects of the design and operation of the first Polish residential micro-CHP unit based on solid oxide fuel cells, Journal of Power Technologies 2016;96(4):270-275).
Kwiatkowski, K., Krzysztoforski, J., Bajer, K., \& Dudyński, M. (2013). Bioenergy from feathers gasification-Efficiency and performance analysis. Biomass and bioenergy, 59, 402-411.

Liu, L., Huang, Y., Cao, J., Liu, C., Dong, L., Xu, L., \& Zha, J. (2018). Experimental study of biomass gasification with oxygen-enriched air in fluidized bed gasifier. Science of The Total Environment, 626, 423-433.

Omar M.M.,Munir A.,Ahmad M.,Tanveer A.,(2018) Downdraft gasifier structure and process improvement for high quality and quantityproducer gas production, Journal of the Energy Institute, Volume 91, Issue 6,1034-1044.

Santarelli M., Briesemeister L., Gandiglio M., Hermann S., Kuczynski P., Kupecki J., Lanzini A., Llovell F., Papurello D., Spliethoff H., Swiatkowski B., Torres-Sanglas J., Vega L.F., Carbon recovery and re-utilization (CRR) from the exhaust of a solid oxide fuel cell (SOFC): analysis through a proof-of-concept, Journal of $\mathrm{CO}_{2}$ Utilization 2017; 18:206-221.

Wei L.,Thomasson J.A.,Bricka R.,M.,Sui.,Wooten J.,R.,Columbus E.,P., (2009) Syn-Gas Quality Evaluation for Biomass Gasification with a Downdraft Gasifier. Transactions of the ASABE, 52(1), 21-37. 